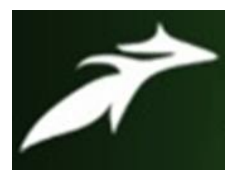

Shivansh Pratap Rana et al, International Journal of Advances in Agricultural Science and Technology, Vol.8 Issue.3, March-2021, pg. 57-64

ISSN: 2348-1358

Impact Factor: 6.057

NAAS Rating: 3.77

\title{
EFFECT OF GIBBERELLIC ACID PRE- TREATMENTS ON GROWTH PARAMETERS OF WALNUT (Juglans regia L.)
}

\author{
Shivansh Pratap Rana ${ }^{1}$; Suneeta Singh ${ }^{2 *}$; Anil Kumar Saxena ${ }^{3}$ \\ ${ }^{1}$ Research Scholar, Department of Horticulture, School of Agricultural Sciences, SGRR University, \\ Dehradun- 248 001, Uttarakhand \\ ${ }^{2} *$ Assistant Professor \& HOD, Department of Horticulture, School of Agricultural Sciences, SGRR \\ University, Dehradun- 248 001, Uttarakhand \\ ${ }^{3}$ Associate Professor, Department of Soil Science, School of Agricultural Sciences, SGRR University, \\ Dehradun- 248 001, Uttarakhand \\ *Email of corresponding author: drsuneetaksaxena@gmail.com
}

DOI: 10.47856/ijaast.2021.v08i3.006

\begin{abstract}
Present investigation was carried out during the winter season at Horticulture Research block, Department of Horticulture, Shri Guru Ram Rai University, Dehradun, Uttarakhand. To investigate the effect of $\mathrm{GA}_{3}$ treatment on growth attributes and days taken for germination initiation of walnut. The experiment was laid out in randomized block design with three replications and twelve treatments. The treatments comprised following levels of $\mathrm{GA}_{3}$ concentrations viz. 500ppm, $1000 \mathrm{ppm}, 15000 \mathrm{ppm}$ and control in three different replications of Horticultural Research Block. Various observations regarding growth parameters such as leaf length, leaf width, shoot length, shoot width and numbers of days taken for germination initiation of walnut were recorded. The result revealed that treatment of $\mathrm{GA}_{3} 1500 \mathrm{ppm}$ of nursery polybag application found to be beneficial for vegetative characters viz, found to be the most effective treatment for increasing leaf length, shoot length and shoot diameter. In another point of view, $1500 \mathrm{ppm} \mathrm{GA}_{3}$ treatment in polyhouse was found to be profitable as compared to rest of treatments in terms of number of days taken for germination. Apart from this leaf width of $1000 \mathrm{ppm}$ in nursery polybag was found best.
\end{abstract}

Keywords: Germination, Shoot length, Leaf width, Nursery polybag, Polyhouse

\section{Introduction}

Walnut (Juglans regia L.) is an important temperate fruit nut crop which belongs to family of Juglandaceae and is considered native to Persia and North Western Himalayas. The major walnut producing countries are USA, China, France, Turkey and Italy. In India it is cultivated at an altitude of 1200-2200 metres above the mean sea level. The Western Himalayas region of India 


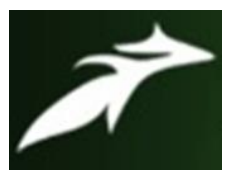

Shivansh Pratap Rana et al, International Journal of Advances in Agricultural Science and Technology, Vol.8 Issue.3, March-2021, pg. 57-64

ISSN: 2348-1358

Impact Factor: 6.057

NAAS Rating: 3.77

comprising of the states of Jammu \& Kashmir, Himachal Pradesh and Uttarakhand are the country's major walnut-producing region.The Juglans genus has 21 species of which Juglans regia is the most important. Apart from this, the seedling trees attain giant size and bear a nut of variable sizes and shapes after 10-15 years where as vegetatively propagated plants are true-totype and produce almost uniform sized nuts after 4-5 years. Seed Dormancy has always been a major problem in germination of seeds. Studies related to the mechanism of seed dormancy have a little different approach. Some seeds are dormant because of the impermeability of the testa to oxygen and water. Stokes (1964) reported that many seeds of temperate fruit crops show dormancy which is overcome by chilling treatment such as in case of apple, pear, peach, plum, apricot etc. However in case of walnut the seed dormancy has been correlated with physiological dormancy that is controlled by seed coat and embryo dormancy. Seed germination is a complex process that started with the absorption of water and after a short pause; the enzyme is activated (Matilla and Matilla-Vazquez, 2008). There are many ways to be followed to break the dormancy in walnut seeds to improve the seed germination i.e., by scarification, stratification and gibberellic acid treatment. Therefore the investigation was carried to test different presowing treatments in an attempt to improve overall growth attributes of walnut seeds in three different replications i.e., in Polyhouse, Nursery polybag and Nursery bed conditions.

\section{Materials and Methods}

The present experiment was carried out during winter season of 2018-19 at the Horticulture Research Block of Department of Horticulture, Shri Guru Ram Rai University, Dehradun, Uttarakhand, India. The fully matured seeds of walnut cultivar (V) 'Chandler' were brought from Jammu and Kashmir. There were twelve different treatments including four gibberellic acid concentrations (500 ppm, $1000 \mathrm{ppm}, 1500 \mathrm{ppm}$ and control) with a combination of three replications of sowing location i.e. Polyhouse (P1), Nursery polybags (P2)and Nursery beds (P3). The selected seeds were participated with the different pre-sowing treatments of stratification for 30 days at $5{ }^{\circ} \mathrm{C}$, scarification with combination of hot water $\left(60^{\circ} \mathrm{C}\right)$ for 6 hours and cold water for 6 hours and finally gibberellic acid treatment for 24 hours with the three different concentrations (500 ppm, $1000 \mathrm{ppm}, 1500 \mathrm{ppm})$ and then these treated seeds were sown in a Randomized Block Design with three replications at a spacing of $(30 \times 15) \mathrm{cm}^{2}$ in Polyhouse bed, Nursery polybag and Nursery bed conditions. The experimental observations of different growth and germination attributes were starts recorded from first week of February, 2019 onwards at fixed interval. All the intercultural operations were followed timely in the different experimental conditions as per the requirement of the crop. From each three experimental conditions randomly selected five plants were used for recording observations for different growth and germination attributes.

\section{Results and Discussion}

The findings of the present investigation were recorded and are thoroughly discussed below: 


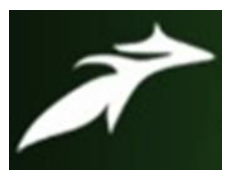

Shivansh Pratap Rana et al, International Journal of Advances in Agricultural Science and Technology, Vol.8 Issue.3, March-2021, pg. 57-64

ISSN: 2348-1358

Impact Factor: 6.057

NAAS Rating: 3.77

\section{Leaf Length and Leaf Breadth (cm)}

The highest calculation in leaf length $(13 \mathrm{~cm})$ was reported in $1500 \mathrm{ppm}$ conc. of $\mathrm{GA}_{3}$ with nursery polybag followed by $(9.33 \mathrm{~cm})$ in $500 \mathrm{ppm}$ conc. of $\mathrm{GA}_{3}$ with nursery polybag, $(8 \mathrm{~cm})$ of control in nursery bed and $(7.78 \mathrm{~cm})$ in $1500 \mathrm{ppm}$ conc. of $\mathrm{GA}_{3}$ with polyhouse as presented in Table 2 and Figure 1. The least count of leaf length is reported only in 500ppm conc. of $\mathrm{GA}_{3}$ with polyhouse beds having $(3.64 \mathrm{~cm})$ followed up by $(3.31 \mathrm{~cm})$ in control of polyhouse beds. The leaf breadth was found excellent $(13 \mathrm{~cm})$ in $1000 \mathrm{ppm}$ conc. of $\mathrm{GA}_{3}$ with nursery polybags followed by the $1500 \mathrm{ppm}$ conc. of $\mathrm{GA}_{3}$ with nursery polybags having the breadth of $(12 \mathrm{~cm})$ of the leaves. The least count of the leaf breadth was found in 500ppm conc. of $\mathrm{GA}_{3}$ with polyhouse beds having a width of $(3 \mathrm{~cm})$. As the further results of the experiments reveals that due the rapid process of cell elongation and cell division the leaf expansion take place which causes leaves broader and elongated length. Sinha et al. (1977); Sharma and Singh (1980) and Martin et al. (2012) also mentioned similar observations as a leaf size in effect of stratification and plant growth regulating substance on seed germination and seedling growth in apples.

\section{Shoot Length $(\mathrm{cm})$ and Shoot Width $(\mathrm{mm})$}

Data revealed in Table 2 and Figure 2 indicates that the best shoot length was recorded in three different concentration of $1500 \mathrm{ppm}$ of $\mathrm{GA}_{3}$ with nursery polybag having $(1.24 \mathrm{~cm}), 500 \mathrm{ppm}$ of $\mathrm{GA}_{3}$ with nursery polybag having $(1.16 \mathrm{~cm})$ and $1000 \mathrm{ppm}$ of $\mathrm{GA}_{3}$ with nursery polybag having $(1.01 \mathrm{~cm})$. Shoot length of $(0.36 \mathrm{~cm})$ in $1500 \mathrm{ppm}$ conc. of $\mathrm{GA}_{3}$ with nursery was founded least measured. Shoot width was best in $1500 \mathrm{ppm}$ of $\mathrm{GA}_{3}$ with nursery polybag measured $(1.09 \mathrm{~mm})$ followed by $1500 \mathrm{ppm}$ of $\mathrm{GA}_{3}$ with polyhouse beds which have $(0.94 \mathrm{~mm})$ shoot width while $1000 \mathrm{ppm}$ of $\mathrm{GA}_{3}$ with nursery polybags recorded $(0.91 \mathrm{~mm})$ shoot width. Thus, $(0.31 \mathrm{~mm})$ shoot width was measured in 500ppm of $\mathrm{GA}_{3}$ with polyhouse beds and control of nursery polybags was measured $(0.32 \mathrm{~mm})$ least. The similar observations for both shoot length and breadth was also recorded by Mathur (1964) and Nabil (2007) in peach and apricot seedlings and the increase in seedling height with GA might be related to the fact that GA promote stem and shoot elongation through the increase of both cell division and from internodes elongation in higher plant (Hopkins and Huner, 2004; Kumar et al., 2014).

\section{Number of days taken for initiation of Germination}

The rapidity in number of days taken for germination was found under the 1500ppm conc. of $\mathrm{GA}_{3}$ with polyhouse beds was the best having (14 days) after sowing followed by (15 days) in $1000 \mathrm{ppm}$ conc. of $\mathrm{GA}_{3}$ with polyhouse beds and (16 days) in 500ppm conc. of $\mathrm{GA}_{3}$ with polyhouse beds. The highest number of days taken for germination was recorded in Control of Nursery having (57days) of germination after sowing followed up by 500ppm conc. of $\mathrm{GA}_{3}$ with Nursery having (52 days) of germination after sowing. Research done by Negi et al., (2016) while working on the effect of $\mathrm{GA}_{3}$ on germination percentage of walnuts in Uttarakhand condition also observed that there was an early germination within (12.67 days) and best germination (75.88\%) with a combination of cracking with $750 \mathrm{ppm} \mathrm{GA}_{3}$ and 


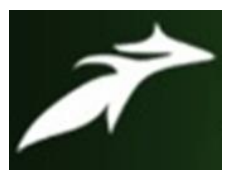

Shivansh Pratap Rana et al, International Journal of Advances in Agricultural Science and Technology, Vol.8 Issue.3, March-2021, pg. 57-64

ISSN: 2348-1358

Impact Factor: 6.057

NAAS Rating: 3.77

stratification for 30 days. As the $\mathrm{GA}_{3}$ plays an important role by exerting its effects on a variety of different processes rapidly as in case of walnuts it helps the necessary enzymes to convert storage polymers into sucrose or amino acids rapidly by digestion processes of is $\alpha$ amylase which is stimulated by Gibberellic acid synthesized in the scutellum (cotyledon) or other parts of the embryo. So, there will be an increase in the number of days taken for initiation of germination. Bal et al; Bhan and Sharma; and Heidari et al. were reported similar results in different temperate crops.

\section{Conclusion}

The conclusion obtained from the results recorded in the present studies showed that the among the following different pre-sowing treatments, the best results in terms of Leaf Length, Leaf Breadth Shoot Length Shoot Width and Number of days taken for initiation of Germination were obtained with scarification + stratification for 30 days + gibberellic acid @ 500 ppm, 1000ppm, $1500 \mathrm{ppm}$ and control amongst three different location (Table:1).The maximum Number of days taken for initial Germination was recorded with control in nursery bed sown walnuts while, the maximum leaf length was recorded in scarification + stratification for 30 days $+\mathrm{GA}_{3}$ @ $1500 \mathrm{ppm}$ concentration of nursery polybags was found to be very effective. Among the growth attributes, like leaf width was recorded highest with scarification + stratification for 30 days + $\mathrm{GA}_{3} @ 1000 \mathrm{ppm}$ of nursery polybags. However, shoot width and shoot length results was recorded maximum with scarification + stratification for 30 days $+\mathrm{GA}_{3} @ 1500 \mathrm{ppm}$ of Nursery polybags which was measured with overall growth of walnut seedlings.

\section{References}

1. Bal, J.S., Satish, K., Rambani, J.L. and Chauhain, P.S. 1990. Effect of growth regulators and stratification periods on seed germination and seedling growth in wild pear (Pyrus pashia). Haryana Journal of Horticultural Sciences, 19: 13-17.

2. Bhan, S. and Sharma, N. 2007. Effect of seed stratification and chemical treatments on seed germination and subsequent seedling growth of wild apricot (Prunus armeniaca L.). Research Journal of Agricultural Sciences, 2(1): 13-16.

3. Heidari, M., Rahemi, M. and Daneshvar, M.H. 2008. Effects of mechanical, chemical, scarification and stratification on seed germination of Prunus scoparia (Spach.) and Prunus webbii (Spach.) Vierh. American-Eurasian Journal of Agriculture and Environmental Science 3(1): 114-117.

4. Hopkins, W.G. and Hüner, N.P. 2004. Introduction of Plant Physiology. 3rd Edition. John Wiely and Sons, Inc. USA.

5. Kumar, A., Nautiyal, M.C. and Prakash, S. 2014. Enhancement of pear (Pyrus pashia L.) seed germination by $\mathrm{GA}_{3}$ and ethanol. Current Science, 57: 964-966. 


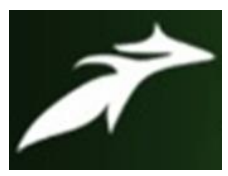

Shivansh Pratap Rana et al, International Journal of Advances in Agricultural Science and Technology, Vol.8 Issue.3, March-2021, pg. 57-64

ISSN: 2348-1358

Impact Factor: 6.057

NAAS Rating: 3.77

6. Mathur, D.D., Couvillon, G.A., Vines, H.M. and Hendershoot, C.H. 1971.Stratification effects on endogenous gibberellic acid in peach seed. Hort Science 6: 538-539.

7. Martin, G.C., Mason, M.I. and Forde, H.I. 2012. Changes in endogenous growth substances in the embryo of Juglans regia during stratification Journal of American Society for Horticulture Sciences 102: 145-148.

8. Nabil, M. and Al-Ameen, A. 2007. Effect of Soaking periods, Gibberellic acid and Benzyl adenine on Pistachio seed germination and subsequent seedling growth (Pistacia vera L.). Mesoptaia. Journal of Agriculture, 35(2): 187-197.

9. Negi, N.D., Sharma, S.K. and Pathania, A. 2016. Studies on the effect of various dormancy breaking treatments on pistachio (Pistacia vera L.) seed germination and seedling growth. Himachal Journal of Agricultural Research 37(2): 181-186.

10. Sinha, M.M., Pal, R.S. and Awasthi, D.N. 1977. Effect of stratification and plant growth regulating substance on seed germination and seedling growth in apples. Progressive Horticulture 9: 27-30.

11. Sharma, H.C. and Singh, R.N. 1980. Effect of stratification, temperature and duration on the level of endogenous inhibitor and its relationship with dormancy in peach seeds (Prunus persica). Indian Journal of Plant Physiology, 23: 26-32.

12. Stokes, P. 1965. Temperature and seed dormancy. In: Ruhland W. (Eds.), Encyclopedia of Plant Physiology, 15/2. Springer-Verlag, Berlin, Heidelberg and New York, Pp. 746803.

Table 1: Details of treatments used in present experiment

\begin{tabular}{|c|c|c|}
\hline S.No. & Symbol & Treatments \\
\hline 1. & VP1T1 & $\mathrm{GA}_{3} @ 500 \mathrm{ppm}+$ Scarification+ Stratification+ Polyhouse bed \\
\hline 2. & VP1T2 & $\mathrm{GA}_{3} @ 1000 \mathrm{ppm}+$ Scarification+ Stratification+ Polyhouse bed \\
\hline 3. & VP1T3 & $\mathrm{GA}_{3} @ 1500 \mathrm{ppm}+$ Scarification+ Stratification+ Polyhouse bed \\
\hline 4. & VP1T4 & Control + Polyhouse \\
\hline 5. & VP2T5 & $\mathrm{GA}_{3} @ 500 \mathrm{ppm}+$ Scarification+ Stratification+ Nursery Polybag \\
\hline 6. & VP2T6 & $\mathrm{GA}_{3} @ 1000 \mathrm{ppm}+$ Scarification+ Stratification+ Nursery Polybag \\
\hline 7. & VP2T7 & $\mathrm{GA}_{3} @ 1500 \mathrm{ppm}+$ Scarification+ Stratification+ Nursery Polybag \\
\hline 8. & VP2T8 & Control + Nursery Polybag \\
\hline 9. & VP3T9 & $\mathrm{GA}_{3} @ 500 \mathrm{ppm}+$ Scarification+ Stratification+ Nursery bed \\
\hline 10. & VP3T10 & $\mathrm{GA}_{3} @ 1000 \mathrm{ppm}+$ Scarification+ Stratification+ Nursery bed \\
\hline
\end{tabular}




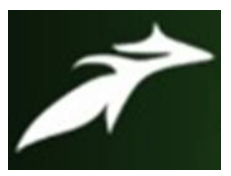

Shivansh Pratap Rana et al, International Journal of Advances in Agricultural Science and Technology,

Vol.8 Issue.3, March-2021, pg. 57-64

ISSN: 2348-1358

Impact Factor: 6.057

NAAS Rating: 3.77

\begin{tabular}{|c|c|c|}
\hline 11. & VP3T11 & GA $_{3} @ 1500 p p m+$ Scarification+ Stratification+ Nursery bed \\
\hline 12. & VP3T12 & Control + Nursery bed \\
\hline
\end{tabular}

Table2: Effect of $\mathrm{GA}_{3}$ with pre-sowing treatment on growth and germination attributes of Walnut seed

\begin{tabular}{|c|c|c|c|c|c|}
\hline Treatments & Leaf Length & Leaf Width & Shoot Length & Shoot Width & $\begin{array}{c}\text { Number of days taken } \\
\text { for germination }\end{array}$ \\
\hline VP1T1 & 3.64 & 3 & 0.43 & 0.31 & 16 \\
\hline VP1T2 & 5.49 & 6 & 0.70 & 0.66 & 15 \\
\hline VP1T3 & 7.78 & 7 & 0.91 & 0.94 & 41 \\
\hline VP1T4 & 3.31 & 4 & 0.36 & 0.39 & 40 \\
\hline VP2T5 & 9.33 & 8 & 1.16 & 0.76 & 39 \\
\hline VP2T6 & 6.99 & 13 & 1.01 & 0.91 & 31 \\
\hline VP2T7 & 13.0 & 12 & 1.24 & 1.09 & 52 \\
\hline VP2T8 & 6.35 & 5 & 0.46 & 0.32 & 43 \\
\hline VP3T9 & 5.59 & 7 & 0.68 & 0.53 & 37 \\
\hline VP3T10 & 5.68 & 6 & 0.55 & 0.48 & 57 \\
\hline VP3T11 & 5.81 & 8 & 0.36 & 0.47 & 4.255 \\
\hline VP3T12 & 8 & 5 & 0.41 & 0.81 & 15.009 \\
\hline ISE m & 1.867 & 2.021 & 0.210 & 0.180 & N/A \\
\hline CD 0.05 & N/A & N/A & N/A & & 47 \\
\hline
\end{tabular}




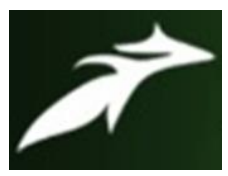

Shivansh Pratap Rana et al, International Journal of Advances in Agricultural Science and Technology, Vol.8 Issue.3, March-2021, pg. 57-64

ISSN: 2348-1358

Impact Factor: 6.057

NAAS Rating: 3.77

Figure 1: Representation of effect of $\mathrm{GA}_{3}$ on leaf length of walnut

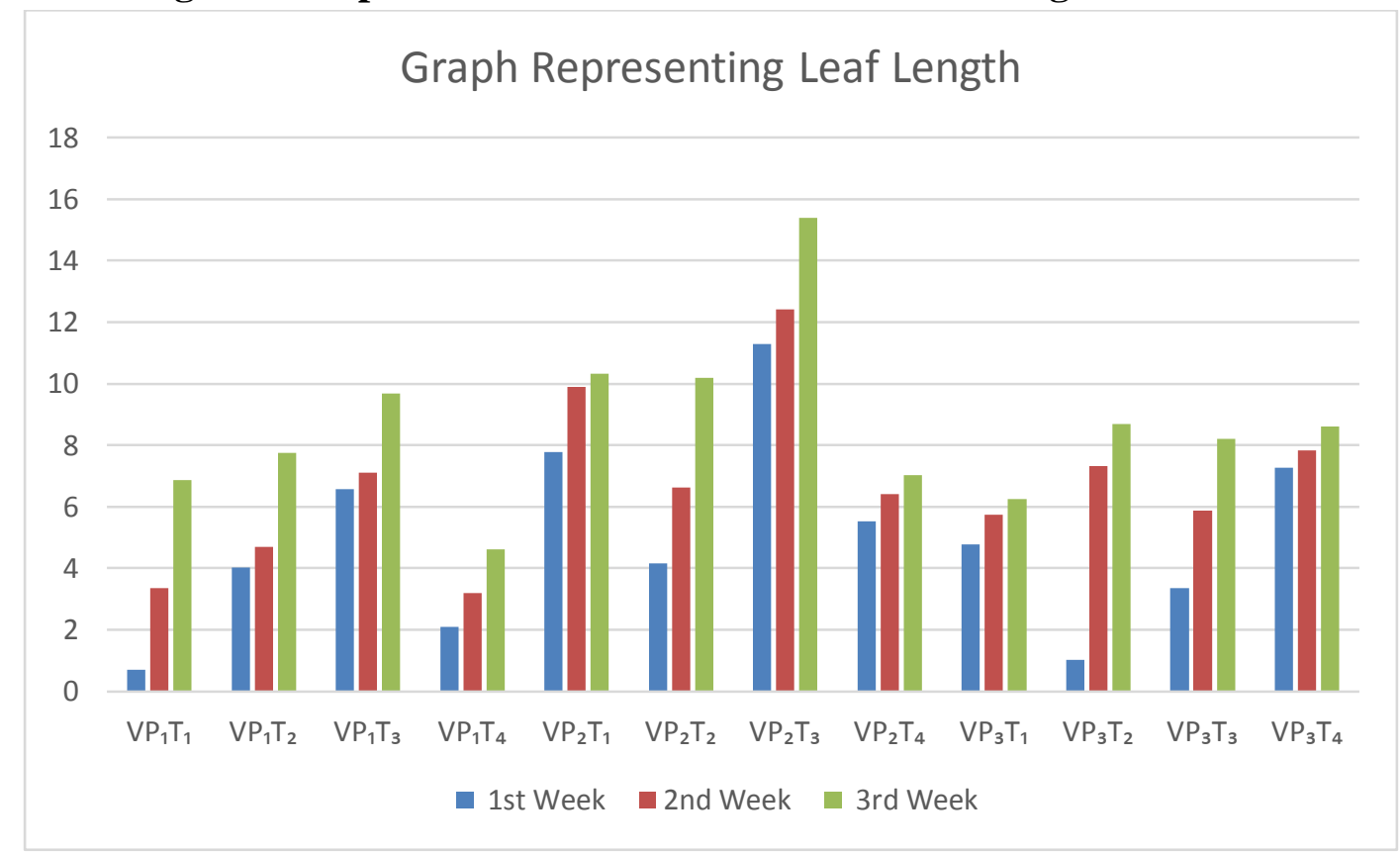

Figure 2: Representation of effect of $\mathrm{GA}_{3}$ on shoot length of walnut

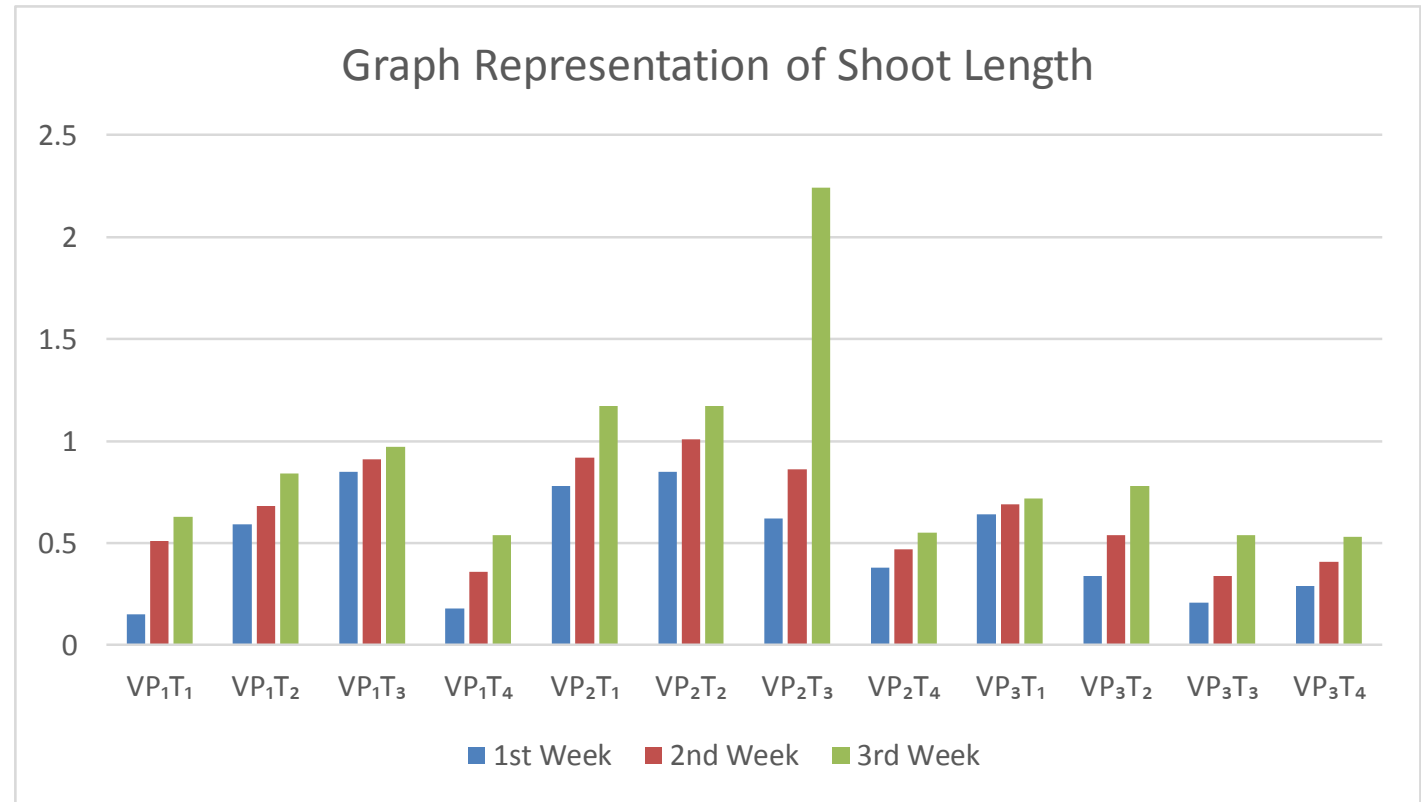




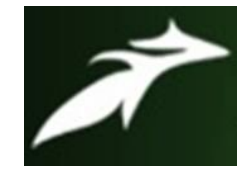

Shivansh Pratap Rana et al, International Journal of Advances in Agricultural Science and Technology, Vol.8 Issue.3, March-2021, pg. 57-64

ISSN: 2348-1358

Impact Factor: 6.057

NAAS Rating: 3.77

Figure 3: Representation of effect of $\mathrm{GA}_{3}$ on number of days taken for germination

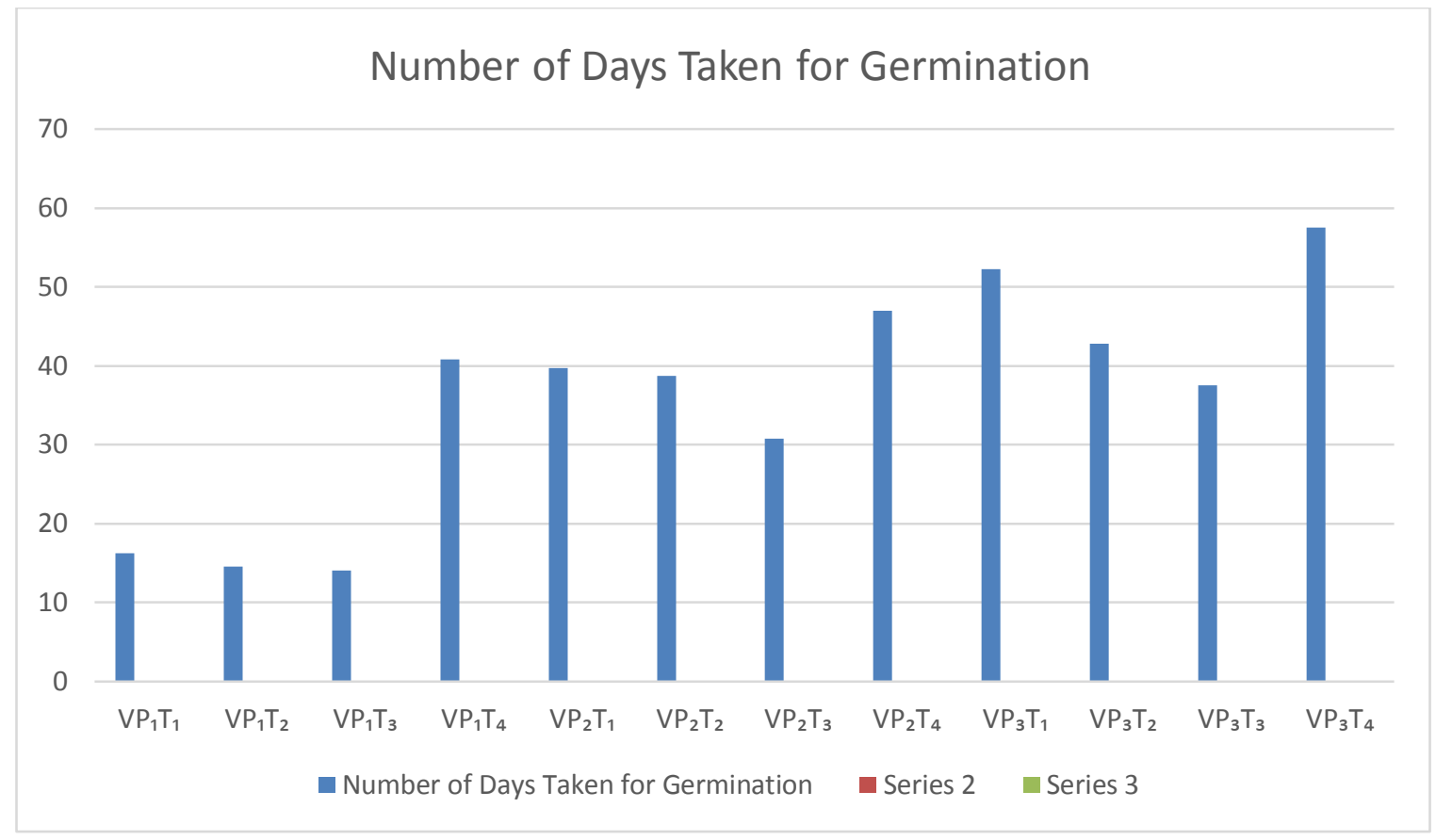

